\title{
Effects of the invertebrate infauna on early saltmarsh plant colonisation of managed realignment areas in south-east England
}

\author{
O. A. L. Paramor ${ }^{1,2}$, R. G. Hughes ${ }^{1, *}$ \\ ${ }^{1}$ School of Biological Sciences, Queen Mary and Westfield College, University of London, London E1 4NS, UK \\ ${ }^{2}$ Present address: School of Biological Sciences, University of Liverpool, Bioscience Building, Crown Street, \\ Liverpool L69 7ZB, UK
}

\begin{abstract}
Saltmarsh erosion on the subsiding coastline of SE England is a major conservation problem and necessitates increased expenditure on maintaining sea walls. The preferred management solution is selective managed realignment (set-back), where sea walls are breached to allow new intertidal land to develop into saltmarsh. We tested the hypothesis that saltmarsh would not necessarily develop in low-lying realignment sites on subsiding coasts, because the accreting sediment would be colonised first by infaunal invertebrates, particularly the polychaete Nereis diversicolor, which would prevent development of vegetation through bioturbation and herbivory. The hypothesis was supported by data on the distributions of the plants and invertebrates in the experimental managed realignment sites at Tollesbury and Orplands, and from infauna exclusion experiments. Tollesbury mostly developed into mudflat colonised mainly by $N$. diversicolor and Hydrobia ulvae, with only a narrow zone of saltmarsh vegetation in the highest area where little sediment had accreted. In contrast, most of the Orplands site was relatively high and, apart from some low-lying basins, little sediment accretion occurred and the area was soon largely covered with saltmarsh vegetation. In experimental $N$. diversicolor exclusion areas, the abundance of microphytobenthos and filamentous algae and sediment accretion increased at both sites, but saltmarsh vegetation only developed at Orplands, probably because the seeds at Tollesbury were buried by rapidly accreting sediment. Further management of low-lying realignment areas is necessary to prevent invertebrate colonisation and help promote saltmarsh development. The experiments also indicate that marsh regeneration need not depend on realignment and should be possible on existing mudflats.
\end{abstract}

KEY WORDS: Managed realignment $\cdot$ Saltmarsh restoration $\cdot$ Nereis diversicolor

\section{INTRODUCTION}

The saltmarshes of the UK have incurred extensive losses in the past few decades, especially in SE England (Burd 1992, Coastal Geomorphological Partnership 2000), where the estimated annual erosion of 40 ha in the county of Essex alone (see Fig. 1A) is two thirds of the total UK losses (Hughes \& Paramor 2004). This loss of saltmarshes has huge implications for conservation, as the marshes are important in the ecology of the estuaries of Essex, which are of international importance as they include Ramsar and Natura 2000 sites. Under the 1992 EU Habitats Direc- tive, the UK is committed to restoring and maintaining saltmarshes to the total area present in 1992 (Covey \& Laffoley 2002), therefore over 750 ha (in 2005) have to be recreated, plus 60 ha for each succeeding year. In SE England, as elsewhere, saltmarshes are also important for coastal defence as they offer some protection from erosive wave action. Dixon \& Weight (1995) calculated that a sea wall behind $80 \mathrm{~m}$ of saltmarsh need only be $3 \mathrm{~m}$ high, at a cost of $£ 400$ per $\mathrm{m}$, as opposed to $12 \mathrm{~m}$ high, at a cost of $£ 5000$ per $\mathrm{m}$, if no marsh is present. The annual loss of saltmarshes in SE England has been valued at £6 million (Hughes \& Paramor 2004). 

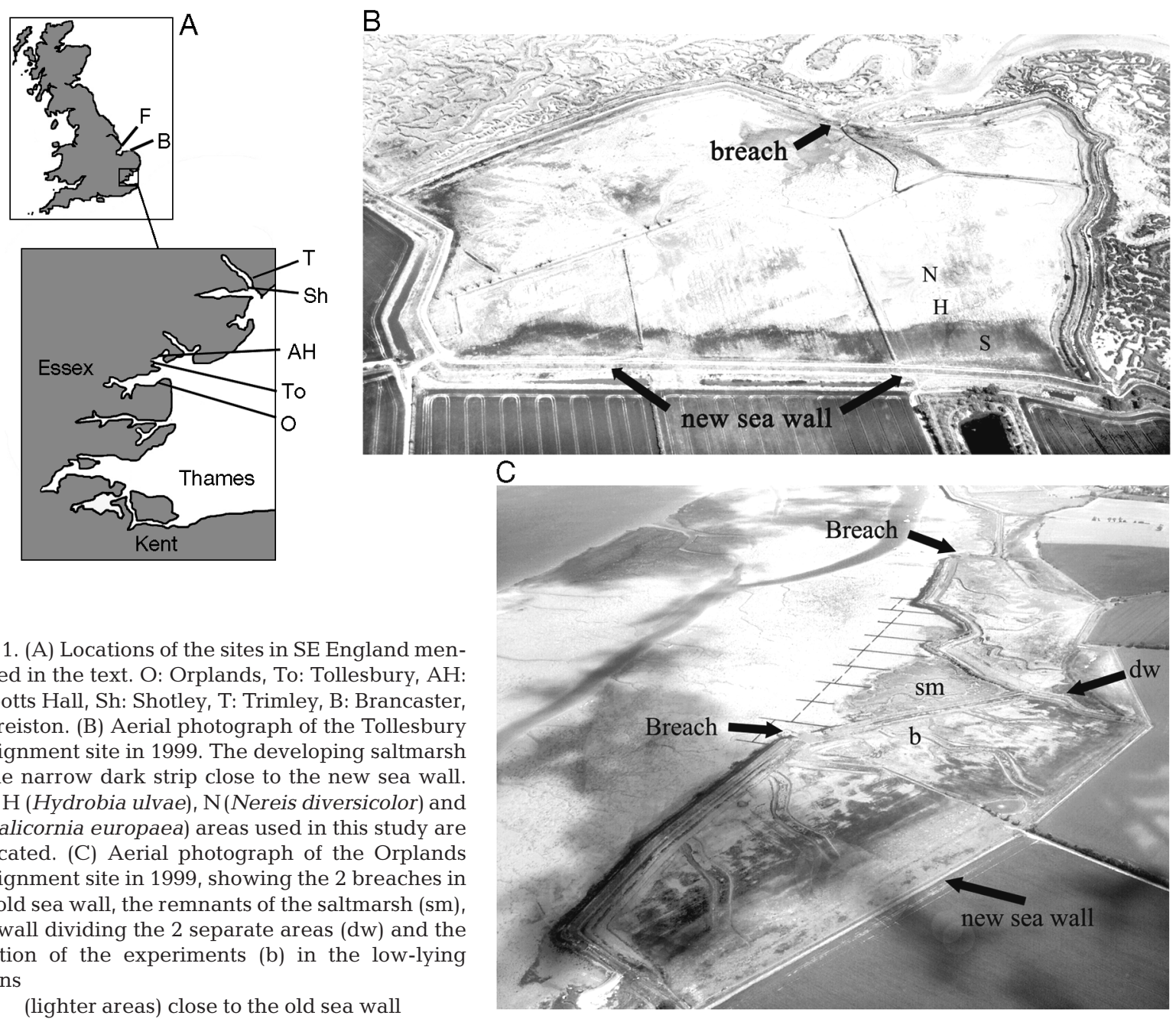

Fig. 1. (A) Locations of the sites in SE England mentioned in the text. O: Orplands, To: Tollesbury, AH: Abbotts Hall, Sh: Shotley, T: Trimley, B: Brancaster, F: Freiston. (B) Aerial photograph of the Tollesbury realignment site in 1999. The developing saltmarsh is the narrow dark strip close to the new sea wall. The H (Hydrobia ulvae), N(Nereis diversicolor) and $\mathrm{S}$ (Salicornia europaea) areas used in this study are indicated. (C) Aerial photograph of the Orplands realignment site in 1999, showing the 2 breaches in the old sea wall, the remnants of the saltmarsh (sm), the wall dividing the 2 separate areas (dw) and the location of the experiments (b) in the low-lying basins

1999), as the new saltmarsh will be required to protect the new sea wall, if one is present, and will help meet a number of conservation objectives.

The acceptance of coastal squeeze as the explanation for saltmarsh losses in SE England has led to the perception that the only means for creating saltmarsh is by providing habitat for the plants at higher elevations through managed realignment. In 1995, 2 experimental managed realignment sites were established in the Blackwater Estuary (Essex), at Tollesbury and Orplands (Fig. 1A). Subsequently many more managed realignment sites have been created, or are planned, in the UK (including Freiston [78 ha], Brancaster [7.5 ha], Abbotts Hall [84 ha] and Wallasea Island [110 ha] in SE England), and elsewhere in NW Europe (Wolters et al. 2005), particularly in The Netherlands (Bakker et al. 2002, de Jonge \& de Jong 2002, Eertman et al. 2002, Nienhuis et al. 2002) and the low-lying coasts of Germany (Bernhardt \& Koch 2003). In the USA there is a much longer history of saltmarsh restoration (Zedler 2001) than in NW Europe, where until relatively recently saltmarsh enclosure and ent of saltmarshes in realignment sites defines the success (Ministry of Agriculture, Fisheries and Food

\section{(also called managed retreat, set-back and de-polder-} . Managed realignment involves breaching or lowering the sea wall (or allowing it to fail) so that an area of land behind the wall becomes intertidal, often up to a new smaller sea wall built on higher ground. The devel- 
embanking were the dominant coastal management practices. Realignment schemes in Europe are being progressively driven by European Union legislation rather than economic considerations, particularly where specific ecological end-points are required in mitigation for lost habitats. Consequently knowledge of the processes that occur in realignment sites is essential if they are to be managed to the desired (e.g. saltmarsh to protect new sea walls) or required (in mitigation) end-points, and the fates of the Tollesbury and Orplands realignment sites have attracted international interest.

Hughes \& Paramor (2004) argued for the rejection of coastal squeeze as an explanation for saltmarsh loss in SE England, principally because the response of saltmarshes to sea level rise is not only to move inland but also to accrete vertically (at the same rate as rising sea level) and to possibly move seawards as well. These 3 processes have led to the development of extensive saltmarshes on the south east coast over several thousand years of sea level rise. Although sea walls reduce their landward movement and halt an increase in their area, coastal defences cannot explain the widespread loss of saltmarsh area in the past half-century. Paramor \& Hughes (2004) presented evidence that loss of saltmarsh vegetation from the pioneer zone, and by internal erosion of saltmarsh creeks, was exacerbated by bioturbation and herbivory by the infauna, particularly the ragworm Nereis diversicolor. $N$. diversicolor may occur high in the intertidal zone where they are predominantly surface deposit-feeders and consume microphytobenthos (Smith et al. 1997), filamentous algae (Hughes 1999) and the seeds and seedlings of saltmarsh plants (Hughes et al. 2000, Paramor \& Hughes 2004). Bioturbation by the amphipod Corophium volutator may also destabilise the sediment and prevent establishment of seedlings of saltmarsh plants (Gerdol \& Hughes 1993).

The conclusion that the loss of saltmarshes cannot be attributed to coastal squeeze, and that some of the loss can be attributed to the activities of the infauna, raises 2 questions. Firstly, is managed realignment the only, or the most appropriate, mechanism available for creating new saltmarsh? Secondly, will managed realignment necessarily generate new saltmarsh? This study addresses the second question. In SE England, as on other subsiding coasts, most of the potential realignment areas are previously claimed saltmarshes and since their enclosure, sometimes several centuries ago, the drained land has shrunk and compacted, while local sea level has continued to rise. Consequently these areas are lower than the remaining saltmarshes (Burd 1995) and sediment accretion would be required to reach an elevation suitable for saltmarsh plant growth. Hughes (2001) predicted that this sediment would first become colonised by infaunal inverte- brates, as they have a lower distribution on the shore, and these would then prevent pioneer saltmarsh development, just as they do in the existing marshes. This hypothesis is tested here by describing the distributions of the plants and invertebrates that colonised the realignment sites at Tollesbury and Orplands, and by field experiments. The experiments were designed to test the specific hypothesis that exclusion of surface deposit-feeding Nereis diversicolor (the most abundant infaunal invertebrate) would lead to enhanced rates of sediment accretion, and higher densities of microphytobenthos, filamentous algae and vascular plants than in nearby control areas.

\section{MATERIALS AND METHODS}

Site description. The Tollesbury realignment site was 21 ha of arable land divided into 4 fields, 1 by the breach and 3 in front of the new sea wall (Fig. 1B). The experimental area was in the easternmost of these 4 fields. In 1997, after $2 \mathrm{yr}$, most of the site had accreted 5 to $10 \mathrm{~cm}$ of sediment, except on the higher ground close to the new wall where no significant accretion had occurred. Here Salicornia europaea agg. was present at densities of up to $500 \mathrm{~m}^{-2}$ at $4.2 \mathrm{~m}$ above chart datum (CD) (hereafter all elevations are $m$ above $C D$ ), together with lower densities of Suaeda maritima, Sarcocornia perennis, Spergularia media and Puccinellia maritima. MHWNTL is $3.80 \mathrm{~m}$ and MHWSTL $5.10 \mathrm{~m}$.

Three distinct habitat types were sampled (Fig. 1B). These were (a) areas of the developing mudflat (3.6 to $3.8 \mathrm{~m}$ elevation in 1997) that remained relatively wet at low tide and were characterised by high densities of the mudsnail Hydrobia ulvae on the surface ( $\mathrm{H}$ area) and low densities of Nereis diversicolor burrows, (b) areas of the mudflat at the same elevations but with drier mud, fewer $H$. ulvae and higher densities of $N$. diversicolor burrows ( $\mathrm{N}$ area) and (c) the higher (above $4 \mathrm{~m}$ ) area close to the new sea wall colonised by saltmarsh plants, predominantly Salicornia europaea (S area).

The Orplands managed realignment site (Fig. 1C) is on the southern shore of the Blackwater Estuary, $4 \mathrm{~km}$ south east of Tollesbury. The flooded area of 38 ha is divided into two by a dividing wall, and each area has a separate breach. Most of the flooded land was above MHWNTL, and thus higher than most of the Tollesbury site, consequently the rates of sediment deposition were expected to be lower at Orplands. By 1997 most of the site had been colonised by pioneer zone vegetation (Salicornia europaea, Suaeda maritima and Spartina anglica), although often at low densities. Little sediment accretion had occurred except in some relatively low-lying areas which had developed into 
mud-filled basins inhabited by infaunal invertebrates (Fig. 1C). These basins were used for the experiments.

Tollesbury: spatial and temporal variations in invertebrate distribution and abundance. Five cores of sediment $(7.5 \mathrm{~cm}$ diameter, $20 \mathrm{~cm}$ depth) were collected periodically (at least every $4 \mathrm{mo}$ ), from October 1997 to September 2000, from each of the 3 areas. The sediment was difficult to sieve because of its high clay content so the invertebrates were removed from the cores by hand instead, as described by Paramor \& Hughes (2004).

Tollesbury: field experiments. Concurrent observations of the heights of 2 flooding and ebbing tides in the realignment site and in the creeks of the adjacent inner marsh showed that the tidal curves in the 2 areas were identical. When the lowest pioneer zone plants Salicornia europaea in the adjacent saltmarsh were reached by the flooding tide, at an elevation of $3.6 \mathrm{~m}$, only about half of the bare mudflat in the realignment site was flooded, indicating that the upper mudflat was at an elevation suitable for these plants. To test the hypothesis that Nereis diversicolor were responsible for the absence of plants from these areas of mudflat 3 types of biodegradable mats (eromat, mulchmat and net) were laid on the sediment surface. The mats achieve the long-term exclusion of the worms by preventing them from feeding on the sediment surface. Paramor \& Hughes (2004) conducted similar experiments in the adjacent marsh and give a full rationale of this approach and details of the methods.

These experiments were conducted in the $\mathrm{N}$ and $\mathrm{H}$ areas of the mudflat 10 to $30 \mathrm{~m}$ from the edge of the Salicornia europaea (S) area, and within the S area to confirm that the mats did not deter colonisation by plants. In January 1998, 5 groups of 3 mats, each group containing a $1 \mathrm{~m}^{2}$ mat of each type, were pinned onto the sediment in each of the 3 areas. For each group an adjacent $1 \mathrm{~m}^{2}$ area of sediment was designated as a control at the outset. Various samples were taken from each mat and control area every 3 mo for a year. The depth of sediment accreted above each mat was measured directly using a rule. An area of $5 \times 5 \mathrm{~cm}$ of each mat, and the sediment above it, was removed and placed immediately in the dark and frozen within $5 \mathrm{~h}$ of collection. After thawing, the mat material and sediment were separated and any invertebrates removed identified and counted. The lengths of any Nereis diversicolor found were measured and any vascular plants also identified and counted. The chlorophyll $a$ of the microphytobenthos and filamentous algae in the remaining sediment was measured using the methods described by Paramor \& Hughes (2004). In the adjacent control areas cores of sediment ( $7.5 \mathrm{~cm}$ diameter, $20 \mathrm{~cm}$ depth) were collected. The top $2 \mathrm{~cm}$ was separated from the rest of the core, and treated as described above. The deeper burrowing invertebrates were removed from the rest of these cores, identified and counted.

This experiment did not facilitate growth of vascular plants, unlike the similar concurrent experiments in the adjacent saltmarsh (Paramor \& Hughes 2004), for several possible reasons. The mats were placed in January when most of the seeds had been shed from the Salicornia europaea plants on higher ground and would therefore already have been in the sediment. Furthermore, most $S$. europaea seedlings were grouped around the remains of the parent plants indicating that seed dispersal distances were low. Consequently in July 1999 another experiment was established to overcome a possible paucity of seeds in the experimental area. Five $1 \mathrm{~m}^{2}$ mulchmats were pinned to the mudflat surface and a box core $(25 \times 25 \times 10 \mathrm{~cm}$ deep) of sediment with seedlings from the $\mathrm{S}$ area (20 to $30 \mathrm{~m}$ away) was transplanted into a hole of the same dimensions cut in the centre of each mat. Five similar box cores of sediment and seedlings were transplanted into the mudflat nearby as controls.

Orplands: field experiments. Similar exclusion experiments were conducted at Orplands. In December 1998, five $1 \mathrm{~m}^{2}$ squares of mulchmat and net were pinned in pairs to the surface of the sediment in 5 separate low-lying basins that had accumulated sediment in the preceding $3 \mathrm{yr}$. Five adjacent $1 \mathrm{~m}^{2}$ control areas were identified at the same time. After 6 mo the depths of sediment accreted on the mats were measured with a rule. The sediment accreted over the mats was higher than that in the control areas. The difference in elevation was measured by placing a $2 \mathrm{~m}$ flat bar horizontally on 2 stakes and measuring the distance from the bar to the surface of the sediment. The elevation of each mat and control area was taken as the mean of 5 measurements. Plant densities were estimated by placing a $0.25 \mathrm{~m}^{2}$ quadrat in the centre of each mat and control area and the plants within the quadrats were identified and counted. The invertebrate densities in the sediment over the mats and in the control areas were estimated using the methods described above. The depths of sediment accretion and plant densities were measured again in August 2000 (after 20 mo).

\section{RESULTS}

\section{Tollesbury: temporal variations in invertebrate distribution and abundance}

The dominant invertebrates in the realignment site at Tollesbury were Nereis diversicolor and Hydrobia ulvae, but the bivalve Macoma balthica occurred occasionally although rarely at high densities (Fig. 2). The visual separation of the mudflat into 2 different 

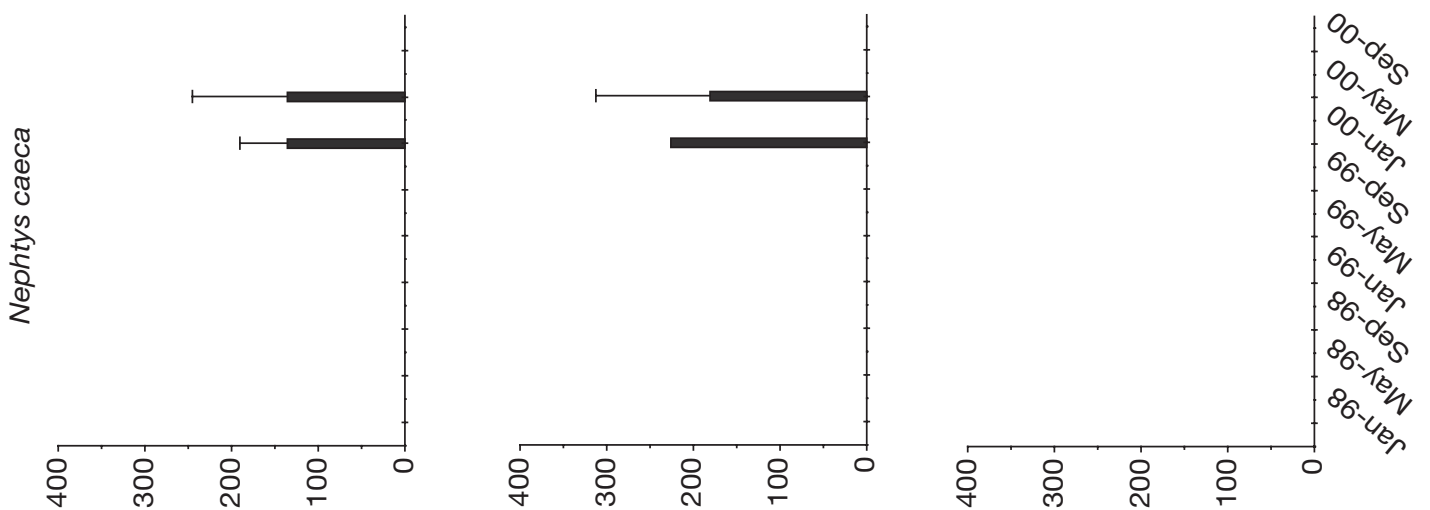

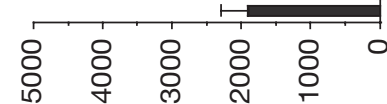

г-m :Ou

вәле $\mathrm{N}$
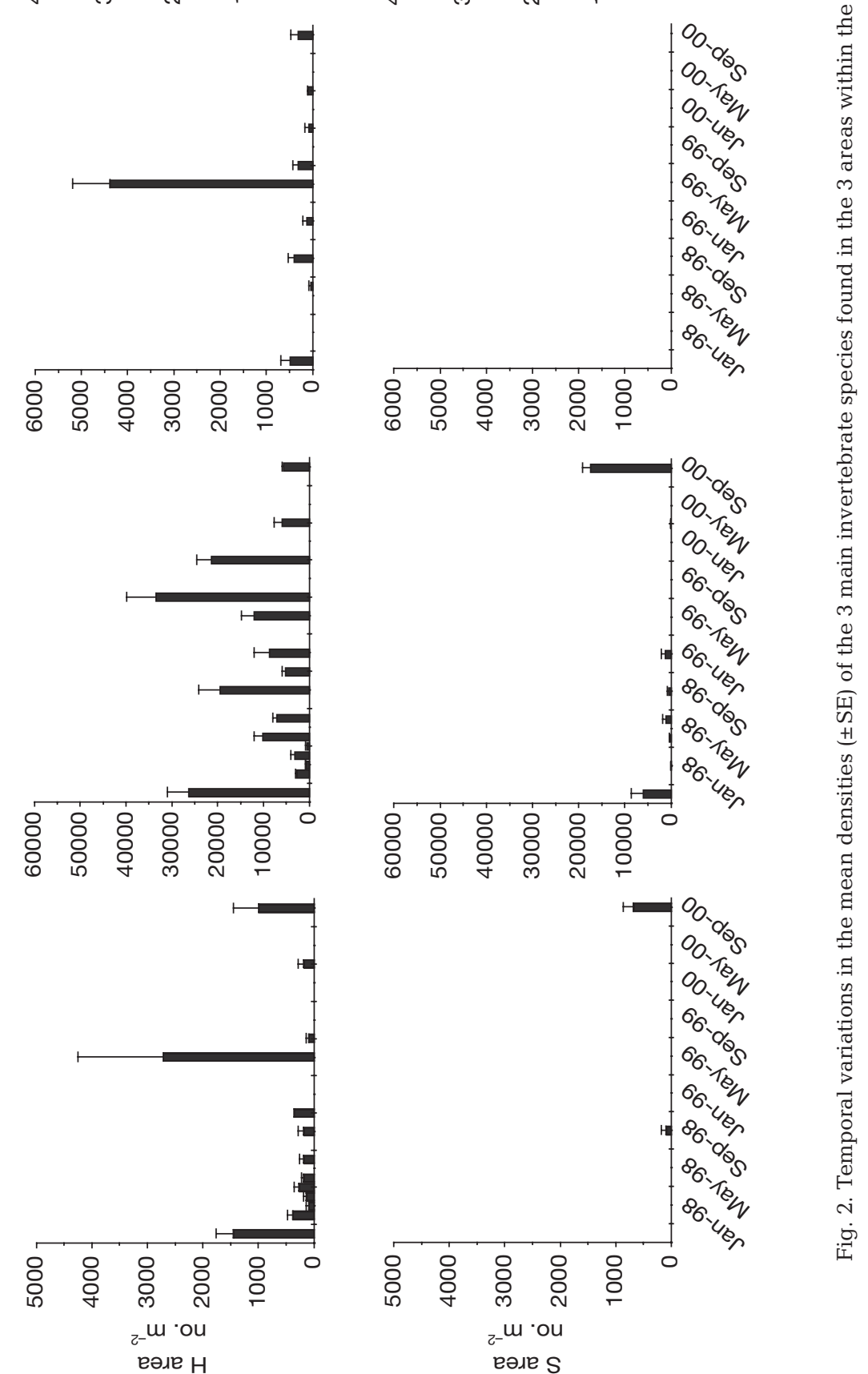
areas was confirmed by the initial data that showed that $H$. ulvae were indeed most abundant in the wetter $\mathrm{H}$ area and $N$. diversicolor were most abundant in the drier $\mathrm{N}$ area. However this distinction was temporary and by January 2000 there was no difference in the abundance of the 2 species in these 2 areas. The abundance of $N$. diversicolor in the 2 mudflat areas varied from $180 \mathrm{~m}^{-2}$ to $2700 \mathrm{~m}^{-2}$, and they were mostly absent from the Salicornia europaea area until September 2000 when a mean density of $678 \mathrm{~m}^{-2}$ was recorded. $H$. ulvae were more widely distributed, being abundant in the 2 mudflat areas and among (and on) the $S$. europaea plants, although at relatively low densities until September 2000 when over $17000 \mathrm{~m}^{-2}$ were recorded. No long term temporal trends in the abundance of $H$. ulvae and $N$. diversicolor were apparent but generally both species were least abundant in winter.

\section{Tollesbury: exclusion experiments}

Within each area the rates of sediment accretion over the different types of mat were similar and the data from them have been combined. In all 3 areas a progressive increase in the depth of sediment was recorded (Fig. 3), particularly in the $\mathrm{H}$ and $\mathrm{N}$ areas where in March, June and September the locations of the buried mats were identified because of the higher elevations of sediment over them. However, in January, the sediment over these mats had been levelled to that of the surrounding sediment, probably by winter storms, and these measured rates of accretion, of $4 \mathrm{~cm}$ over the year, were applicable to the whole mudflat. Only approximately $0.5 \mathrm{~cm}$ of sediment had deposited in the Salicornia europaea area in 1 yr.

Within the first 3 mo relatively high densities of Nereis diversicolor had colonised the accreting sediment above the mats in the 2 mudflat areas (Fig. 4). These worms were new recruits and they were all shorter than $2 \mathrm{~cm}$, while worms up to $10 \mathrm{~cm}$ long were found in control areas (Fig. 5). Recruitment of small worms continued through the summer, particularly over the mats where several $100 \mathrm{~m}^{-2}$ were recorded. By September most of the large worms had disappeared from the control areas and the size frequencies of the juvenile worms above the mats

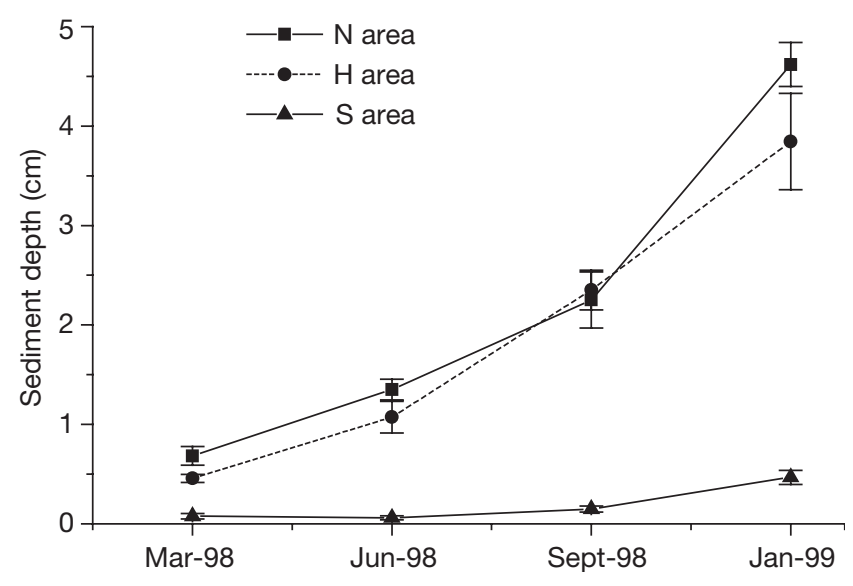

Fig. 3. Mean $( \pm \mathrm{SE})$ depth of sediment deposited over the experimental mats placed in January 1998 in the 3 areas (see Fig. 1 for abbreviations) in the Tollesbury realignment site

and in the control areas were not different. No worms were found above the mats in January. By September there was a distinct post-recruitment peak in abundance of Hydrobia ulvae and Macoma balthica (Fig. 4), when the bivalves were significantly more abundant over the mats than in the control areas (see Fig. 2). By January these 2 species had also suffered a significant decline in abundance. The exclusion experiments were not expected to affect $H$. ulvae distri-
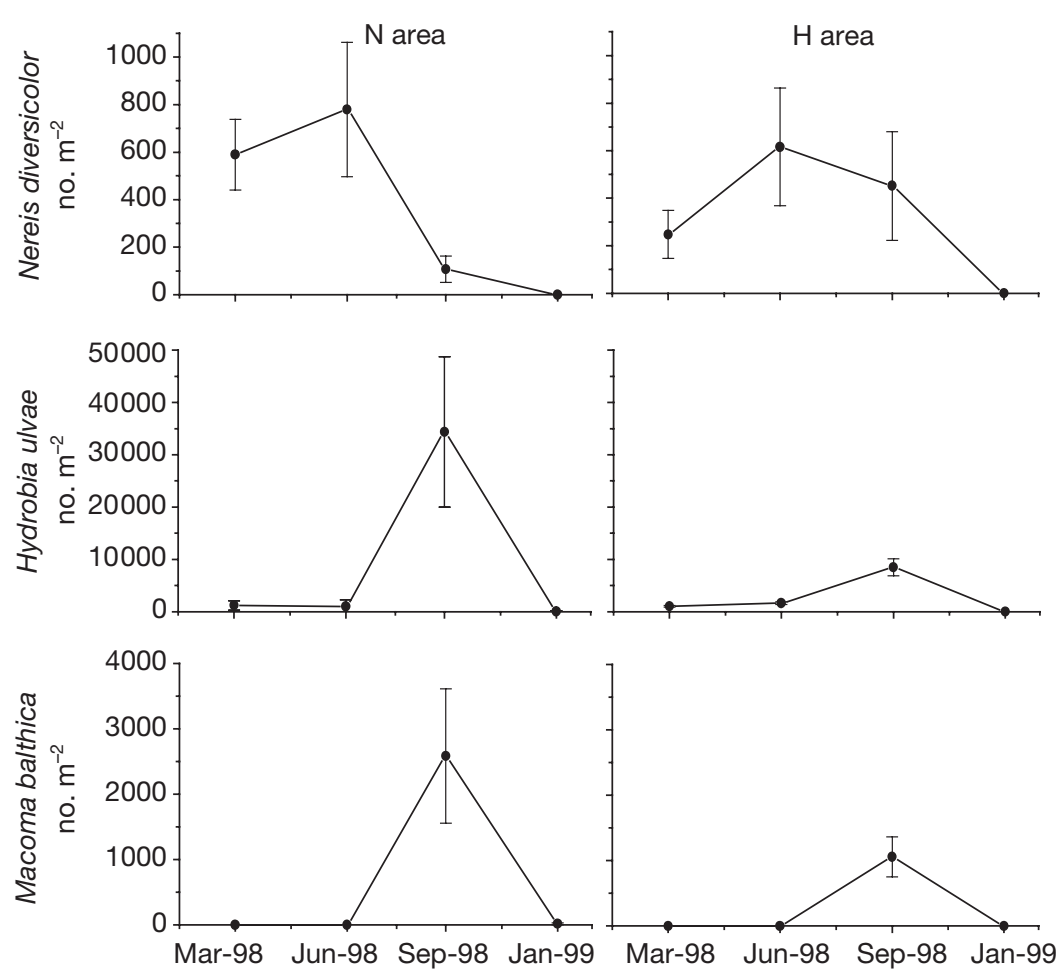

Fig. 4. Mean $( \pm \mathrm{SE})$ density of invertebrates in sediment above the mats placed in January 1998 in the Tollesbury realignment site 


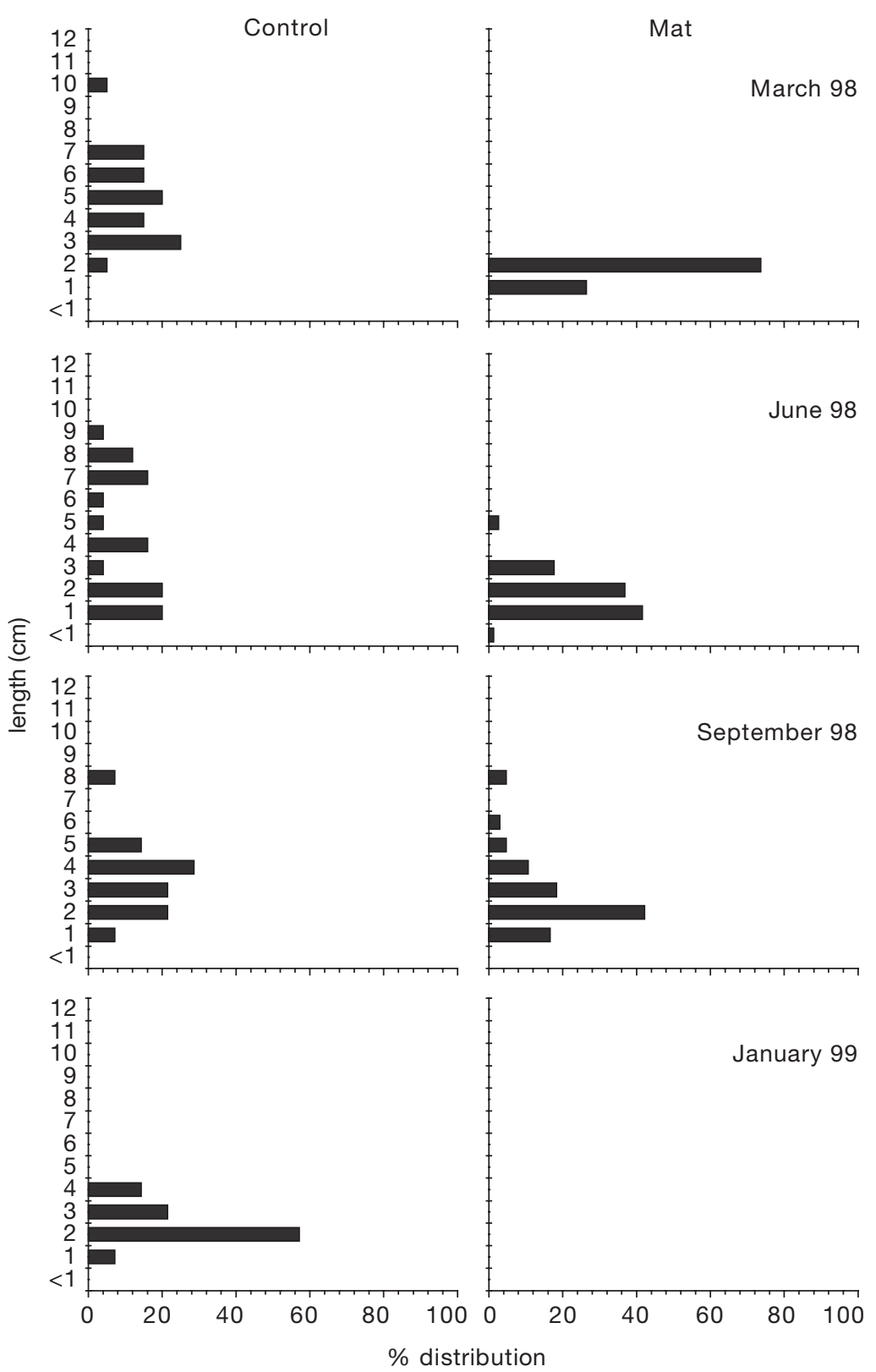

Fig. 5. Nereis diversicolor. Length frequency distribution (\%) of ragworms in control areas and shallow sediments accreted over the experimental mats in the Tollesbury realignment site

butions, as the small gastropods were able to move freely over the sediment surface.

In the $\mathrm{H}$ and $\mathrm{N}$ areas a distinct bloom of microphytobenthos developed on the accreting sediment over the mats by March and this was followed by a dense growth of filamentous Enteromorpha sp. by June. This is reflected in the significantly higher chlorophyll a contents of the sediment than the controls from March to September (with one exception) (Fig. 6). By January the abundance of the microphytobenthos and Enteromorpha had declined and the amounts of chlorophyll $a$ over the mats were not different to the controls. In the Salicornia europaea area the chlorophyll a contents of the sediments were low and there was no consistent difference between the mats and the control areas. Mats in the S area only were colonised by vascular plants (S. europaea), at a mean density of $23( \pm 3.2 \mathrm{SE}) \mathrm{m}^{-2}$, indicating that the mats themselves did not prevent plant colonisation.

In the second experiment the Salicornia europaea plants transplanted into the centre of the mats and control areas grew normally, matured and produced seeds in the autumn. However, by the summer of 2000 only a few seedlings of the next generation were found over the mats (a mean of $3.5 \mathrm{~m}^{-2}$ ), although none were found in the control areas. Both areas had accreted a mean of $3.5 \mathrm{~cm}$ of sediment in $1 \mathrm{yr}$.

\section{Orplands: exclusion experiments}

The mean depth of sediment deposited on these mats was $1.69( \pm 0.12 \mathrm{SE}) \mathrm{cm}$ in the first $6 \mathrm{mo}$ and $2.43( \pm 0.87 \mathrm{SE}) \mathrm{cm}$ after 20 mo. The elevation of this sediment above the adjacent control sediment after 6 mo was approximately $1 \mathrm{~cm}$ indicating that only about $0.5 \mathrm{~cm}$ had accreted in the control areas.

Nereis diversicolor, Hydrobia ulvae and Macoma balthica dominated the infauna of the control areas, with some diptera larvae also present. After 6 mo the same 3 species had colonised the sediment above the mats (Fig. 7). Although the mean densities of $N$. diversicolor and $H$. ulvae were approximately half and double those of the controls respectively, the variability in the data meant that the densities were not significantly different to the controls. However, the differences in sizes of $N$. diversicolor between the mat and control areas were similar to those described for Tollesbury (see above).

After 5 mo the mats were colonised by Salicornia europaea, (95.6 $\left.\pm 11.9 \mathrm{~m}^{-2}\right)$, Suaeda maritima (0.8 \pm $\left.0.4 \mathrm{~m}^{-2}\right)$ and Enteromorpha ( $40 \pm 9.1 \%$ cover $)$ whilst all the control areas remained bare. After 20 mo the mats bore high densities of $S$. europaea $\left(580.6 \pm 140.7 \mathrm{~m}^{-2}\right)$ and Spartina anglica $\left(76.5 \pm 16.02 \mathrm{~m}^{-2}\right)$, but no $S$. maritima (Fig. 8). The adjacent control areas remained bare. 


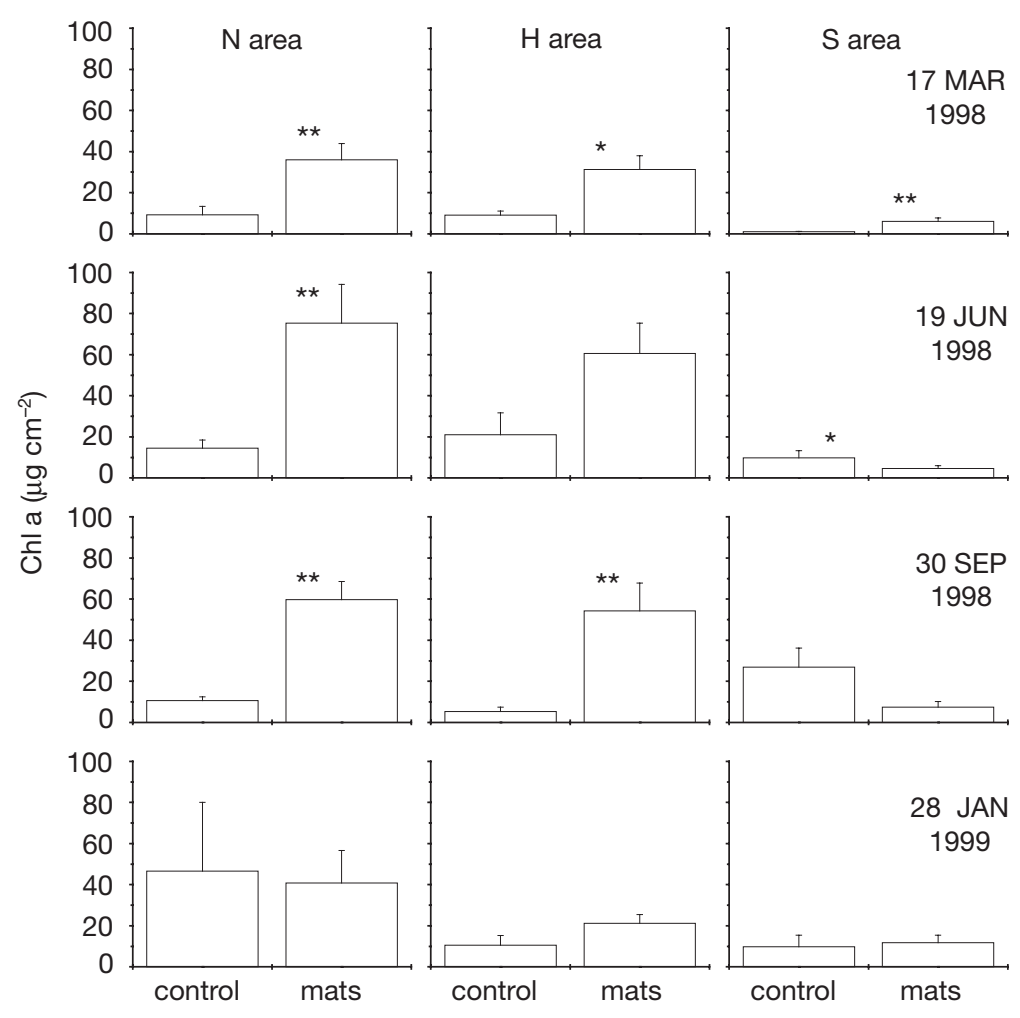

Fig. 6. Mean $( \pm \mathrm{SE})$ concentration of chlorophyll $a$ in the sediment over the experimental mats and in control areas in the Tollesbury realignment site. The significance of differences between treatment (mats) and controls are shown $\left({ }^{*} \mathrm{p}<0.05 ; * * \mathrm{p}<0.005\right)$
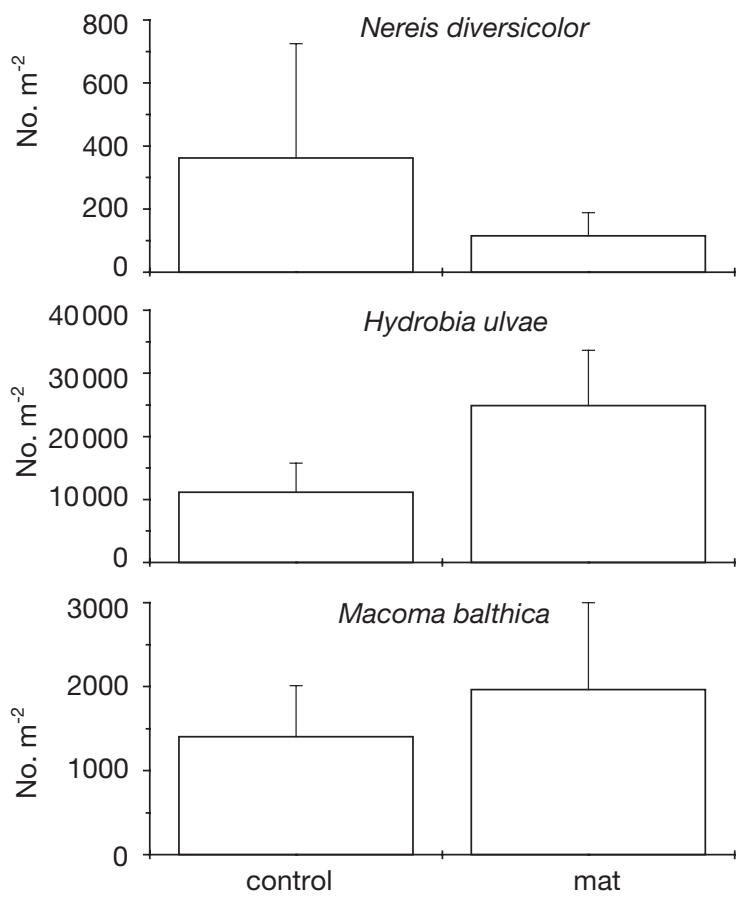

Fig. 7. Mean $( \pm \mathrm{SE})$ abundance of the 3 invertebrate species in control areas and shallow sediments accreted over the experimental mats in the Orplands realignment site

\section{DISCUSSION}

After 2 yr (from the commencement of this study) only a small uppermost area of the Tollesbury site had been colonised by saltmarsh plants (mostly Salicornia europaea and Suaeda maritima), while most of the Orplands site had vegetation, although the plants were at low densities. These vegetated areas had not experienced high rates of sediment accretion, and even after 10 yr (in 2005) there were only thin layers of marine sediment over the previously agricultural soil. At both sites no infauna were found in the areas where pioneer zone vegetation had developed, despite being within the elevational range of Nereis diversicolor (Paramor \& Hughes 2004). At Tollesbury their absence was attributed to the dense vegetation, the roots of which inhibited burrowing (Paramor \& Hughes 2004), but at Orplands the density of plants was much lower and it is likely that the soil, with little accreted sediment, was too hard and compact for them to burrow into. By contrast, most of the Tollesbury site and the low-lying basins at Orplands had accumulated marine sediment which had been colonised by $N$. diversicolor, at densities similar to those in existing mudflats of SE England (R. G. Hughes pers. obs.). These areas were bare of vegetation, and remain so after $10 \mathrm{yr}$, except at Orplands where the experimentally created $1 \mathrm{~m}^{2}$ patches of vegetation have persisted.

The exclusion of large Nereis diversicolor is seen as the reason why increased abundances of microphytobenthos (seen at both sites, but chlorophyll a was measured only at Tollesbury), filamentous algae (both sites), enhanced rates of sediment accretion (both sites) and higher densities of vascular plants (Orplands only) were seen in the exclusion areas. The failure of the experiments at Tollesbury to facilitate colonisation by Salicornia europaea, can be attributed to the high rate of sediment deposition there (e.g. approximately $2.5 \mathrm{~cm}$ between November 1998 and April 1999, compared to $0.5 \mathrm{~cm}$ between December 1998 and May 1999 at Orplands). These differences reflect the original differences in the elevation of the 2 sites, and the inverse relationship between elevation and rates of sediment deposition (Pethick 1981). Burial of seeds even by shallow layers of sediment significantly inhibits the development of seedlings (Paramor 2002). Clearly some seeds were not buried too deeply in the exclusion areas 


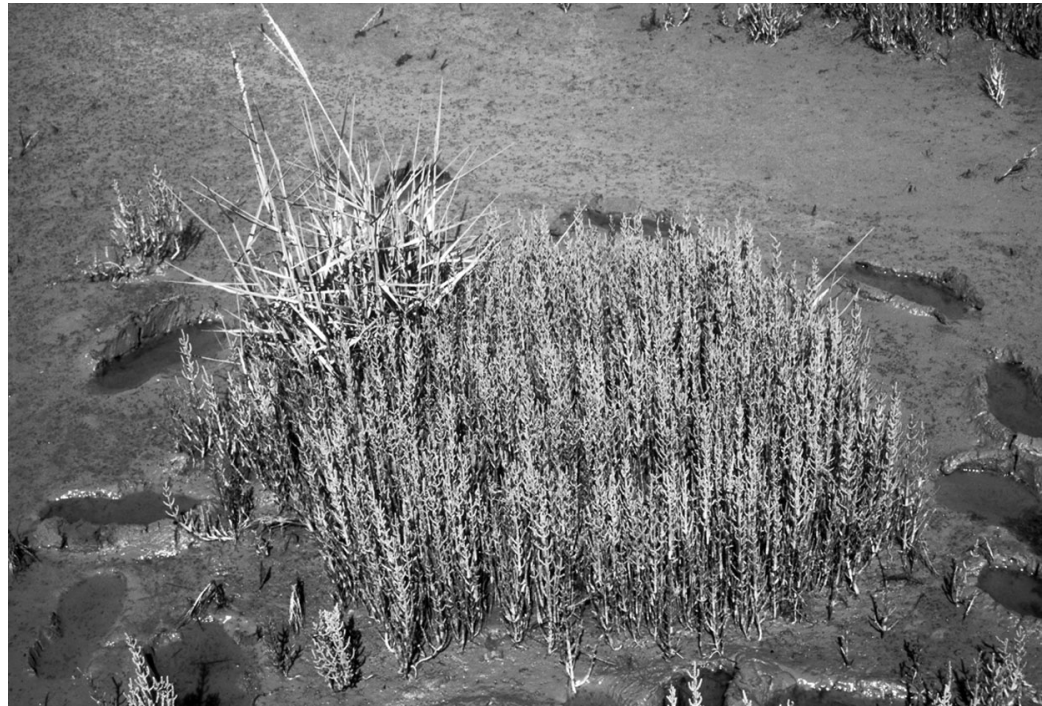

Fig. 8. Saltmarsh vegetation that developed over a $1 \mathrm{~m}^{2}$ mat after 20 mo in the Orplands realignment site

at Orplands or in the control areas where the rates of sedimentation were even lower. The absence of plants in these control areas is attributed to the activities of $N$. diversicolor. The development of vegetation in the exclusion areas at Orplands and not in the control areas is the most convincing evidence in support of the hypothesis that colonisation of accreting sediment by infaunal invertebrates, particularly $N$. diversicolor, in low-lying realignment sites would precede, and then prevent, development of saltmarsh vegetation.

Three other factors that may reduce colonisation of intertidal mud by plants are habitat elevation, seed supply and water movement. The experiments at Tollesbury were placed at an elevation suitable for Salicornia europaea, as demonstrated by their presence at lower elevations in the adjacent marsh, and the survival to maturity of the transplanted seedlings, and a few of their progeny, in the second experiment. The experiments were 20 to $30 \mathrm{~m}$ from the $S$. europaea zone, in contrast to those at Orplands that were within 1 to $2 \mathrm{~m}$ of the established vegetation. A naturally low rate of supply of seeds from this distance may have been important. Paramor (2002) recorded an exponential decline in the abundance of $S$. europaea seeds with distance from the vegetated area. However, a lack of seeds cannot explain the lack of seedlings on the mats with plants transplanted in their centre. Wiehe (1935) identified water movement as a factor restricting the lower distribution of $S$. europaea and concluded that seedlings could only establish above MHWNTL where they would remain undisturbed for some consecutive days during neap tides. Water movement may have contributed to the lack of seedlings in the experiments at Tollesbury but the successful experiments at Orplands were also below MHWNTL and the effects of water movement cannot account for the differences in plant densities between the experimental and control areas there. The seedlings developing over the mats would not have been stabilised by the mats themselves because of the accretion of sediment over them.

The exclusion of large Nereis diversicolor may have had other effects on the biota. Small N. diversicolor and Macoma balthica sometimes had relatively high densities in the sediment over the mats and could have lessened the effects of the exclusion of large worms on sediment accretion and plant colonisation. Hiddink et al. (2002) concluded that deposit-feeding $N$. diversicolor consumed small $M$. balthica and the sediment above the mats may have been a refuge from predation or disturbance by large $N$. diversicolor. The $N$. diversicolor that colonised the sediments over the mats were relatively small, but by summer there was no difference in the sizes of the worms in the exclusion and control areas because of the decline of the adult cohort in the control areas. By the winter there were no worms or $M$. balthica over the mats, possibly because of migration or predation by wading birds on these animals that could not burrow more deeply. Thus by the time the seeds have dispersed and germinated, in winter and spring, the mats again have low densities of small $N$. diversicolor. This annual cycle of reduced worm abundance may have facilitated colonisation of the sediment over the mats by successive generations of Salicornia europaea at Orplands, because in 2005 the isolated $1 \mathrm{~m}^{2}$ patches of vegetation dominated by these annual plants were still evident.

The prediction that, unless there is a widespread and unexpected reduction in the abundance of the infauna, future low-lying managed realignment sites will be colonised first by infauna which will prevent saltmarsh development is supported by observations of old (unmanaged) realignment sites that remain as bare mudflats (Hughes 2001) and the fate of 2 sedimentrecharge schemes in the Orwell Estuary (approximately $30 \mathrm{~km}$ north of the Blackwater Estuary) (Fig. 1A). At Shotley, a shingle bund in the shape of an elongated $\mathrm{C}$ was constructed on the mudflat in front of a vulnerable sea wall and the enclosed area was recharged twice with mud dredged from deeper water, the second time in 1999, to a level of approximately $0.5 \mathrm{~m}$ above MHWNTL. The aim, to establish saltmarsh, had been unsuccessful by July 2002 when the 
mud contained Nereis diversicolor at mean densities of $520 \mathrm{~m}^{-2}$. At Trimley, a realignment site behind the sea wall was first recharged with sediment to elevations ranging from approximately $1.5 \mathrm{~m}$ below to $0.5 \mathrm{~m}$ above MHWNTL before a breach was cut in the sea wall in 2000. Although it was intended that this site would develop into a mudflat, in mitigation for mudflat losses elsewhere in the Orwell estuary, it too has been colonised by high densities of $N$. diversicolor (at a mean density of $730 \mathrm{~m}^{-2}$ in July 2002), particularly in the higher areas. In both of these sites pioneer zone vegetation has established only on hard clods of soil remaining from construction activities, despite the mudflat being at the appropriate elevation for plants.

The failure of several low-lying realignment sites to establish saltmarsh vegetation casts doubt on their usefulness in saltmarsh restoration. The evidence does not support the contention of Morris et al. (2004) that realignment is effective in managing and reversing saltmarsh erosion (Hughes in press), because relatively small areas have been available for realignment, and as most of these are low-lying the expectation is that these will develop into invertebrate dominated mudflats. The Shotley and Trimley recharge sites confirm that providing sediment at the appropriate elevation for saltmarsh plants is not sufficient, as Nereis diversicolor distribution extends above MHWNTL (Paramor \& Hughes 2004). To ensure the development of saltmarsh flora in realignment sites the land should be at or above MHWNTL, in order to reduce the depth of new sediment accretion, and compacted to a hardness which will deter burrowing infauna. Low-lying land should be recharged with coarser sediment, and possibly compacted prior to flooding, to prevent burrowing by infauna. This would also reduce further accretion and prevent waterlogging which could deter development of vegetation. Crooks \& Pye (2000) considered that the formation of an impermeable aquaclude at the surface of the original soil resulted in waterlogging of the accreted sediment, and this could contribute to the lack of vegetation in the realignment areas that have a high mud/vegetation ratio, even after $100 \mathrm{yr}$.

The development of vegetation in these exclusion experiments indicates that saltmarsh regeneration need not depend on managed realignment. Even if, as generally assumed, the lower limit of saltmarsh vegetation is at MHWNTL, there are large areas of mudflat in these estuaries still exposed when the tides reach this elevation (Hughes \& Paramor 2004). Similar experiments to establish or extend existing saltmarshes could be attempted in these areas. Marsh regeneration here should be possible, and in addition to reducing the rate of erosion of existing marshes (Paramor \& Hughes 2004) would reduce the exposure of sea walls to wave action.
Note added in proof. The explanation for the lack of developing vegetation in the exclusion areas at Tollesbury, that the rate of sedimentation was too high and buried the seeds, has been confirmed by recent experiments by Peter West and R. G. Hughes. Five mulchmats of $0.25 \mathrm{~m}^{2}$ placed in the $\mathrm{N}$ zone of mudflat in 2002 were subjected to a relatively low rate of accreation, probably because of the higher elevation of the sediment. Salicornia europaea plants at high densities covered the mats from 2003, but only by 2005 when about $2.0 \mathrm{~cm}$ of sediment covered these mats can this be attributed to the exclusion of Nereis diversicolor rather than to the presence of the mats themselves.

Acknowledgements. We are grateful to the Department of Environment, Food and Rural Affairs for funding this research, to the several colleagues that helped with field work, particularly P. Fletcher, and to R. Allen (Harwich Haven Authority) for details regarding the 2 Orwell recharge sites.

\section{LITERATURE CITED}

Bakker JP, Esselink P, Dijkema KS, van Duin WE, de Jong DJ (2002) Restoration of salt marshes in the Netherlands. Hydrobiologia 478:29-51

Bernhardt KG, Koch M (2003) Restoration of a salt marsh system: temporal change of plant species diversity and composition. Basic Appl Ecol 4:441-451

Burd F (1992) Erosion and vegetation change on the saltmarshes of Essex and north Kent between 1973 and 1988. Research and Survey in Nature Conservation 42, Nature Conservancy Council, Peterborough

Burd F (1995) Managed retreat: a practical guide. English Nature, Peterborough

Coastal Geomorphological Partnership (2000) Erosion of the saltmarshes of Essex between 1988 and 1998. Department of Marine Sciences and Coastal Management, University of Newcastle, Newcastle

Covey R, Laffoley Dd'a (2002) Maritime state of nature report for England; getting onto an even keel. English Nature, Peterborough

Crooks S, Pye K (2000) Sedimentological controls on the erosion and morphology of saltmarshes; implications for flood defence and habitat recreation. In: Allen JRL, Pye K (eds) Coastal and estuarine environments; sedimentology, geomorphology and geoarchaeology. Geol Soc Spec Publ 175: 207-222

de Jonge VN, de Jong DJ (2002) Ecological restoration in coastal areas in the Netherlands: concepts, dilemmas and some examples. Hydrobiologia 478:7-28

Dixon AM, Weight RS (1995) Managing coastal realignment: Case study at Orplands Sea Wall, Blackwater Estuary, Essex. In: Halcrow W (ed) Saltmarsh management for flood defence. NRA (Project reference 480/1/SW), Anglian Region

Eertman RHM, Kornman BA, Stikvoort E, Verbeek H (2002) Restoration of the Sieperda tidal marsh in the Scheldt estuary, the Netherlands. Restor Ecol 10:438-449

Gerdol V, Hughes RG (1993) Effect of the amphipod Corophium volutator on the colonisation of mud by the halophyte Salicornia europaea. Mar Ecol Prog Ser 97:61-69

Hiddink JG, ter Hofstede R, Wolff WJ (2002) Predation of 
intertidal infauna on juveniles of the bivalve Macoma balthica. J Sea Res 47:141-159

Hughes RG (1999) Saltmarsh erosion and management of saltmarsh restoration; the effects of infaunal invertebrates. Aquat Conserv Mar Freshw Ecosyst 9:83-95

Hughes RG (2001) Biological and physical processes that affect saltmarsh erosion and saltmarsh restoration: development of hypotheses. In: Reise K (ed) Ecological studies: ecological comparisons of sedimentary shores. Springer Verlag, Berlin, p 173-192

Hughes RG (in press) On the loss of saltmarshes in south-east England and the utility of managed realignment in their restoration. J Appl Ecol

Hughes RG, Paramor OAL (2004) On the loss of saltmarshes in SE England and methods for their restoration. J Appl Ecol 41:440-448

Hughes RG, Lloyd D, Ball L, Emson D (2000) The effects of the polychaete Nereis diversicolor on the distribution and transplanting success of Zostera noltii. Helgol Mar Res 54: 129-136

Ministry of Agriculture, Fisheries and Food (1999) Tollesbury managed realignment experimental site: summary report of research and other activities, 1994-1996. Ministry of Agriculture Fisheries and Food, London

Morris RK, Reach IS, Duffy MJ, Collins TS, Leafe RN (2004) On the loss of saltmarshes in south-east England and the relationship with Nereis diversicolor. J Appl Ecol 41:

Editorial responsibility: Victor de Jonge (Contributing Editor), Haren, The Netherlands
$787-791$

Nienhuis PH, Bakker JP, Grootjans AP, Gulati RD, de Jonge VN (2002) The state of the art of aquatic and semi-aquatic ecological restoration projects in the Netherlands. Hydrobiologia 478:219-233

Paramor OAL (2002) Interactions between benthic macroinvertebrates and saltmarsh plants: consequences for saltmarsh restoration and the policy of managed realignment on the coast of SE England. PhD thesis, University of London

Paramor OAL, Hughes RG (2004) The effects of bioturbation and herbivory by the polychaete Nereis diversicolor on loss of saltmarsh in SE England. J Appl Ecol 41:449-463

Pethick JS (1981) Long term accretion rates on tidal saltmarshes. J Sediment Petrol 51:571-577

Smith D, Hughes RG, Cox E (1997) Predation of epipelic diatoms by the amphipod Corophium volutator and the polychaete Nereis diversicolor. Mar Ecol Prog Ser 145: 53-61

Wiehe PO (1935) A quantitative study of the influence of tide upon populations of Salicornia europaea. J Ecol 23: 323-333

Wolters M, Garbutt A, Bakker JP (2005) Salt-marsh restoration: evaluating the success of de-embankments in northwest Europe. Biol Conserv 123:249-268

Zedler JB (2001) Handbook for restoring tidal wetlands. Marine Science Series, CRC Press, Boca Raton, FL

Submitted: February 12, 2005; Accepted: June 11, 2005

Proofs received from author(s): November 1, 2005 